\title{
Exogenous Exposure to Estradiol Benzoate or Flutamide at the Weaning Age Alters Expression of Connexin Isoforms in the Initial Segment of Male Rat
}

\author{
${ }^{\dagger}$ Ki-Ho Lee \\ Dept. of Biochemistry and Molecular Biology, College of Medicine, Eulji University, Daejeon 301-746, Korea
}

\begin{abstract}
Connexin $(C x)$ is a complex which allows direct communication between neighboring cells via exchange of signaling molecules and eventually leads to functional harmony of cells in a tissue. The initial segment (IS) is an excurrent duct of male reproductive tract and expression of numerous genes in the IS are controlled by androgens and estrogens. The effects of these steroid hormones on gene expression in the IS during postnatal development have not extensively examined. The present research investigated expressional modulation of $C x$ isoforms in the IS by exogenous exposure to estrogen agonist, estradiol benzoate (EB), or androgen antagonist, flutamide (Flu), at weaning age. Two different doses of EB or Flu were subcutaneously administrated in 21-day old of male rats, and expressional changes of $C x$ isoforms in the adult IS were analyzed by quantitative real-time PCR. Treatment of a low-dose EB $(0.015 \mu \mathrm{g} / \mathrm{kg}$ body weight $)$ resulted in an increased expression of $C x 31$ gene and a decreased expression of $C x 37$ gene. A high-dose EB (1.5 $\mu \mathrm{g} / \mathrm{kg}$ body weight) treatment caused an increase of $C x 31$ gene expression. Increased levels of $C x 30.3$ and $C x 40$ transcripts were observed with a low-dose Flu (500 $\mu \mathrm{g} / \mathrm{kg}$ body weight) treatment. Treatment of high-dose Flu $(50 \mathrm{mg} / \mathrm{kg}$ body weight) led to expressional increases of $C \times 30.3,40$, and 43 genes. Our previous and present findings suggest differential responsiveness on gene expression of $C x$ isoforms in the IS by androgens and estrogens at different postnatal ages.
\end{abstract}

Key words : Initial segment, Connexin, Estradiol benzoate, Flutamide, Gene expression, Epididymis

\section{INTRODUCTION}

Functional and structural maturation of male reproductive tissues are mostly dependent on the actions of androgens, as well as estrogens (Akingbemi \& Hardy, 2001; Carreau et al., 2008). The epididymis is a part of excurrent ducts in male reproductive tract and is divided into four regions, including initial segments (IS), caput epididymis, corpus epididymis, and cauda epididymis, depending on morphological and functional features (Cosentino \& Cockett, 1986).
The epithelium of IS is characterized with the presence of narrow and apical cells which do not exist throughout the rest of the epididymis (Robaire \& Hermo, 1988). An importance of the IS for proper sperm maturation has been examined by Temple-Smith et al. (1998). Surgical redirection of spermatozoa produced from the testis to the distal part of the caput epididymis results in significant reduction of the fertility (Temple-Smith et al., 1998). In addition, the luminal composition and epithelial enzymatic distribution within the IS are distinguished from the rest of the epi-

\footnotetext{
Manuscript received 10 February 2015, Received in revised form 23 February 2015, Accepted 10 March 2015

${ }^{\dagger}$ Corresponding Author : Ki-Ho Lee, Dept. of Biochemistry and Molecular Biology and Medical Sciences Research Institute, Eulji University, Daejeon 301-746, Korea. Tel. : +82-42-259-1643, Fax : +82-42-259-1649, E-mail : kiholee@eulji.ac.kr

This is an Open Access article distributed under the terms of the Creative Commons Attribution Non-Commercial License (http:// creativecommons.org/licenses/by-nc/3.0) which permits unrestricted non-commercial use, distribution, and reproduction in any medium, provided the original work is properly cited.
} 
didymis (Adamali \& Hermo, 1996; Jones, 1987). Based on these findings, it is considered that the IS plays an important role discriminated from the other parts of the epididymis on sperm maturation

Direct cell-cell communication is a way for regulation and maintenance of functions of tissues and/or organs in coordinated manner. There are three types of direct cell interaction between neighboring cells, including cadherinbased adhesion, occluding-based attachment, and connexin $(C x)$-based gap junction (Pointies et al., 2005). Of these ways, cell-cell communication by gap junction allows direct exchange of signal molecules, RNAs, and ions through the cytoplasm of neighboring cells (Goodenough et al., 1996). Of $20 C x$ isoforms identified in mammals, some $C x$ isoforms are present in virtually all cell types and others are expressed in strict cell types (Meşe et al., 2007). The presence and expression of $C x$ isoforms in the male reproductive tract are exhibited by others and our previous findings. Focused on the epididymis, Dufresne et al. (2003) demonstrate that expression of some $C x$ isoforms during postnatal development is segmentally specific along the epididymis. Our earlier researches have revealed different expressional levels of $C x$ isoforms in different epididymal regions at various postnatal ages (Han \& Lee, 2013; Lee, 2013). In addition, our previous research shows differential expression of $C x$ isoforms in the IS from 1 week to 2 years of postnatal age (Seo et al., 2010). These results imply that postnatal maturation and functional regulation of the IS would relate with exact expression of $C x$ isoforms at correct ages. However, expressional regulation of $C x$ isoforms in the IS is caught less attention. Induced hypothyroidism at neonatal age causes a significant expressional decrease of Cx43 gene in the adult IS (St-Pierre et al., 2003). Also, it seems that epidermal growth factor involves in regulation of $C x 43$ expression in human cauda epididymis (Dubé et al., 2012). Moreover, our recent research demonstrates disruption of expression of $C x$ isoforms in the adult IS by exposure to estradiol benzoate (EB), an estrogen agonist, and/or flutamide (Flu), an androgen antagonist, at 1 week of postnatal age (Lee, 2014). Expressional changes of some $C x$ isoforms are dose-dependent or steroidal hormonespecific but expression patterns of others are not (Lee, 2014). For examples, treatments with ED at 0.015 and 1.5 $\mu \mathrm{g} / \mathrm{kg}$ body weight (BW) result in increased expression of $C x 30.3$ and $C x 43$. However, expression of $C x 31$ gene is not affected by $0.015 \mu \mathrm{g} \mathrm{EB} / \mathrm{kg}$ BW but is decreased by $1.5 \mu \mathrm{g} \mathrm{EB} / \mathrm{kg} \mathrm{BW}$ (Lee, 2014). Expression of $C x 43$ gene increases with treatments of $500 \mu \mathrm{g}$ or $50 \mathrm{mg} \mathrm{Flu/} \mathrm{kg} \mathrm{BW,}$ while transcript levels of $C \times 32$ and $C \times 37$ are only increased by a treatment of $50 \mathrm{mg} \mathrm{Flu/} \mathrm{kg} \mathrm{BW} \mathrm{(Lee,} \mathrm{2014).} \mathrm{Together,}$ the findings from our and other researches strongly imply that expressional regulation of $C x$ gene in the IS is influenced by androgen and/or estrogen in part.

It is generally documented that functions of the epididymis are regulated by the actions of androgen, as well as estrogen (Joseph et al., 2011; Robaire \& Hamzeh, 2011). During the early postnatal period, serum testosterone concentrations are not steady, and expressional levels of androgen and estrogen receptors in the epididymis are gradually increased (Sar \& Welsch, 2000; You \& Sar, 1998). Thus, it is generally considered that responsiveness of the epididymis to androgen and estrogen at different postnatal age would be diverse. Androgen and estrogen chiefly control expression of a number of genes involving in the functional regulation of the epididymis (Joseph et al., 2011; Robaire $\&$ Hamzeh, 2011). As mentioned earlier, expression of $C x$ isoforms in the adult IS are altered by exogenous administration of EB or Flu at 1 week of postnatal age (Lee, 2014). Thus, the present study was designed to determine if hormonal disruption by exposing to EB or Flu at the early or late neonatal age produces similar results in expression of $C x$ isoforms in the adult IS. Unlike treatment at 1 week of age in the previous research, EB or Flu was exogenously administrated at 3 weeks of age. Expressional 
patterns of $C x$ isoforms in the adult IS were analyzed by quantitative real-time polymerase chain reaction.

\section{MATERIALS AND METHODS}

\section{Experimental designs and treatment of steroid hormones}

Pregnant Spragure Dawley rats $(n=5)$ obtained from Samtako (OSan, Korea) were kept in individual cage upon the arrival and randomly assigned into one of experimental groups, including control, low-dose estradiol benzoate (EB) treated (EB-L), high-dose EB treated (EB-H), low-dose flutamide (Flu-L), and high-dose flutamid (Flu-H) group. Free access to food and drinking water was allowed for the experimental period. Five to seven pups were delivered from each female rat and kept together with mother rat until the weaning at 21 days of age.

The EB and Flu were purchased from Tokyo Chemical Industry Co. (Tokyo, Japan). To prepare EB and Flu stock solutions, the powder of hormones was stirred in $100 \%$ EtOH at room temperature until completely dissolved. The stock solutions were diluted in peanut oil to make working solutions. At the weaning, each male pup was weighted, and an amount of steroid hormone being subcutaneously injected was calculated. The final concentrations of EB and Flu were $0.015 \mu \mathrm{g} / \mathrm{kg}$ body weight (BW) for EB-L, 1.5 $\mu \mathrm{g} / \mathrm{kg} \mathrm{BW}$ for EB-H, $500 \mu \mathrm{g} / \mathrm{kg} \mathrm{BW}$ for Flu-L, and $50 \mathrm{mg} /$ $\mathrm{kg} \mathrm{BW}$ for Flu-H. Subcutaneous injection of peanut oil of same amount was applied to animals in control group. The doses of EB and Flu were chosen because a previous research had shown that neonatal treatment of these hormones at the doses resulted in recognizable influences on expression of Cx isoforms in the IS (Lee, 2014)

\section{Tissue collection and total RNA isolation}

At 4 months of age, experimental animals were anestheticzed by $\mathrm{CO}_{2}$ stunning in a chamber. An incision was made on the lower abdomen to expose the reproductive tract. The epididymis was separated from the testis and epididymal fat in cold PBS. Careful dissection was carried out to isolate the IS from the rest of the epididymis. The IS was washed in fresh cold PBS for two times and frozen in liquid nitrogen. The IS was kept in $-80^{\circ} \mathrm{C}$ until utilized for total RNA isolation and cDNA generation. A total of 30 male rats were used for the present study, including control $(n=6)$, EB-L $(n=6)$, EB-H $(n=6)$, Flu-L $(n=6)$, and Flu-H $(\mathrm{n}=6)$.

The frozen IS was homogenized in an Eppendorf tube having total RNA extraction solution (iNtRON Biotech, Sungnam, S.Korea) with a polytron homogenizer (Fisher Scientific, Pittsburgh, PA). Then, a pellet of total RNA was isolated using common phenol-chloroform extraction method. The total RNA in DEPC- $\mathrm{dH}_{2} \mathrm{O}$ was resuspended in DEPC- $\mathrm{dH}_{2} \mathrm{O}$, and the concentration of total RNA was analyzed with an UV spectrophotometer (Eppendorf, New York, USA). In addition, gel electrophoresis was carried out for qualitative evaluation of total RNA samples. The total RNAs were either directly utilized to generate cDNA or stored in $-80^{\circ} \mathrm{C}$ until utilized later for cDNA construction.

\section{Construction of first cDNA strand and analysis of} quantitative real-time PCR

One microgram of total RNA was used to generate the first strand of cDNA in ImProm-II ${ }^{\mathrm{TM}}$ reverse transcription system (Promega, Madison, USA) with oligo-dT primer. The mixture of reverse transcription (RT) reaction was placed in $25^{\circ} \mathrm{C}$ for $5 \mathrm{~min}, 42^{\circ} \mathrm{C}$ for $1 \mathrm{hr}$ and $30 \mathrm{~min}$, and then $70^{\circ} \mathrm{C}$ for $15 \mathrm{~min}$. The constructed cDNA was directly utilized for quantitative real-time PCR to evaluate expressional changes of $\mathrm{Cx}$ isoforms among experimental groups. Oligonucleotide primers for real-time PCR analysis are described in Table 1.

The mixture for real-time PCR included $1 \mu \mathrm{L}$ of cDNA, 10 pmol of each primer, $10 \mu \mathrm{L}$ of master mixture (Finnzymes, Espoo, Finland), and nuclease-free $\mathrm{dH}_{2} \mathrm{O}$ to make a final volume of $20 \mu \mathrm{L}$. The PCR was first placed at $95^{\circ} \mathrm{C}$ for 30 
Table 1. Information of oligonucleotide primers used for quantitative real-time PCR analysis

\begin{tabular}{|c|c|c|c|}
\hline $\begin{array}{c}\text { Gene } \\
\text { (GenBank ID) }\end{array}$ & $\begin{array}{l}\text { Primer sequence } \\
\qquad\left(5^{\prime} \rightarrow 3^{\prime}\right)\end{array}$ & $\begin{array}{c}\mathrm{T}_{\mathrm{m}} \\
\left({ }^{\circ} \mathrm{C}\right)\end{array}$ & $\begin{array}{l}\text { PCR product } \\
\text { size (bps) }\end{array}$ \\
\hline $\begin{array}{c}C x 30.3 \\
\left(\mathrm{NM} \_053984\right)\end{array}$ & $\begin{array}{l}\text { (forward) CCCAATGTCTGCTATGACGA } \\
\text { (reverse) CACAGCAGCCTTGAAGATGA }\end{array}$ & 57 & 243 \\
\hline $\begin{array}{c}C x 31 \\
\left(\mathrm{NM} \_019240\right)\end{array}$ & $\begin{array}{l}\text { (forward) TTGAGCGGTGTGAACCAGTA } \\
\text { (reverse) TGTTGGAGATGGGGAAGAAG }\end{array}$ & 57 & 193 \\
\hline $\begin{array}{c}C x 31.1 \\
\left(\mathrm{NM} \_019241\right)\end{array}$ & $\begin{array}{l}\text { (forward) CATCGTCTGCATCCTGCTTA } \\
\text { (reverse) ATGAGGTCGCTTGAGAGGAA }\end{array}$ & 55 & 165 \\
\hline $\begin{array}{c}C \times 32 \\
\left(\mathrm{NM} \_017251\right)\end{array}$ & $\begin{array}{l}\text { (forward) AGAATCATGGTGCTGGTGGT } \\
\text { (reverse) CCTCAAGCCGTAGCATTTTC }\end{array}$ & 57 & 235 \\
\hline $\begin{array}{c}C x 37 \\
\left(\mathrm{NM} \_021654\right)\end{array}$ & $\begin{array}{l}\text { (forward) AGTGTCTGTACCTTGGATGCC } \\
\text { (reverse) CAGCACACTTAGCCAAGAGC }\end{array}$ & 51 & 223 \\
\hline $\begin{array}{c}C x 40 \\
\left(\mathrm{NM} \_019280\right)\end{array}$ & $\begin{array}{l}\text { (forward) ATACCATTCAGCCTGGTTGC } \\
\text { (reverse) CGGCCTCTTTAGCTTTCTCA }\end{array}$ & 57 & 189 \\
\hline $\begin{array}{c}C x 43 \\
\left(\mathrm{NM} \_012567\right)\end{array}$ & $\begin{array}{c}\text { (forward) AGCAAGCTAGCGAGCAAAAC } \\
\text { (reverse) GAGTTCATGTCCAGCAGCAA }\end{array}$ & 55 & 151 \\
\hline $\begin{array}{c}C x 45 \\
\left(\mathrm{NM} \_001085381\right)\end{array}$ & $\begin{array}{l}\text { (forward) GATCATCCTGGTTGCTACTC } \\
\text { (reverse) GATCCTCTTCATGGTCCTCT }\end{array}$ & 51 & 173 \\
\hline Ppia & $\begin{array}{l}\text { (forward) GGCAAATGCTGGACCAAACAC } \\
\text { (reverse) TTAGAGTTGTCCACAGTCGGAGATG }\end{array}$ & 59 & 196 \\
\hline
\end{tabular}

$C x$ : connexin; Ppia : peptidylprolyl isomerase A (cyclophilin A).

sec for denaturation of RNA and primer strands. Then the PCR was performed in cycles of denaturation stage at $95^{\circ} \mathrm{C}$ for $30 \mathrm{sec}$, annealing stage at $\mathrm{T}_{\mathrm{m}}$ for $30 \mathrm{sec}$, and extension stage at $72^{\circ} \mathrm{C}$ for $30 \mathrm{sec}$. An additional extension step at $72^{\circ} \mathrm{C}$ for 10 min was included at the end of each PCR cycle. Cyclophilin A (Ppia) was included in every PCR for an internal quantitative control purpose. Agarose gel electrophoresis was performed to confirm correct sizes of PCR products.

\section{Statistical analysis and presentation of data}

Of total RNAs isolated from IS tissues, randomly chosen four total RNA samples were used to conduct RT reaction and real-time PCR. Relative expression levels of the $C x$ genes were calculated according to the $2^{-\Delta \Delta \mathrm{Ct}}$ method. Experimental results are present in relative expression ratios between Ppia and $C x$ genes. One-way ANOVA was carried out to determine statistical significance among control and experimental groups of EB or Flu treatment. Whenever the statistical significance was present, a posthoc analysis, Duncan's $t$ test, was applied to find out differences among these experimental groups. A $p$ value < 0.05 was considered statistically significant.

\section{RESULTS}

1. Expressional patterns of $C \times 30.3$ and $C \times 31$ genes in the initial segment of adult male rat after treatment of estradiol benzoate or flutamide at 3 weeks of age

Expression of $C \times 30.3$ in the IS of adult rat was not significantly changed by the treatment of EB at 3 weeks of age (Fig. 1A). Compared with control group, neither lowdose nor high-dose of EB affected the level of gene expression of $C x 30.3$ in the IS, (Fig. 1A). However, the 
A)

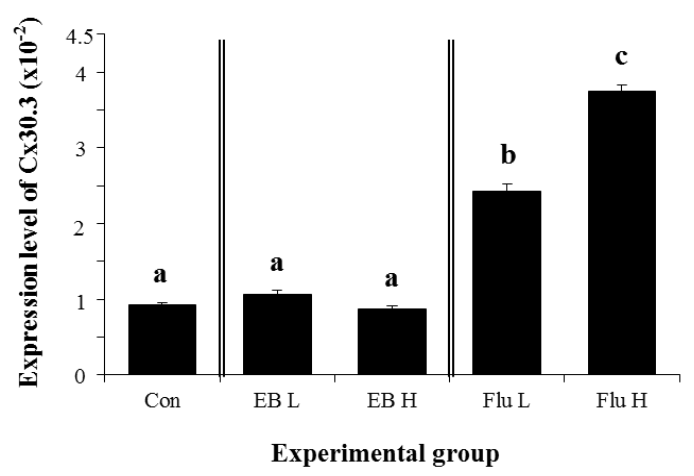

B)

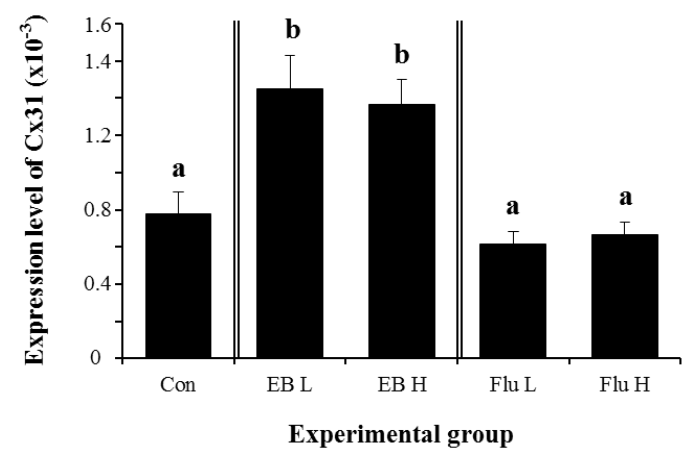

Fig. 1. Expression patterns of $C x 30.3$ and $C x 31$ genes in the initial segment of adult rat. Animals at 3 weeks of postnatal age were treated with either estradiol benzoate at low (EB L, $0.015 \mu \mathrm{g} / \mathrm{kg} \mathrm{BW}$ ) or high (EB H, $1.5 \mu \mathrm{g} / \mathrm{kg} \mathrm{BW}$ ) or flutamide at low (Flu L, $500 \mu \mathrm{g} / \mathrm{kg} \mathrm{BW}$ ) or high (Flu H, $50 \mathrm{mg} / \mathrm{kg}$ BW) dose. Different letters indicate statistically significant differences at $p<0.05$ level, compared with control.

treatment of Flu at low-dose resulted in a significant increase of $C x 30.3$ gene expression (Fig. 1A). A further great increase of $C x 30.3$ expression was induced by highdose Flu treatment (Fig. 1A). Expressional change of $C \times 31$ gene in the IS was observed with EB treatment (Fig. 1B). Treatment of both doses of EB at 3 weeks of age caused significant increases of $C x 31$ gene in the adult IS, even though there was no statistical difference on $C \times 31$ transcript level between low-dose or high-dose EB treatment (Fig. 1B). Unlike $C x 30.3$, the treatment of Flu didn't give an influence on gene expression of $C x 31$ in the IS (Fig. 1B).
2. Expressional patterns of $C \times 31.1$ and $C \times 32$ genes in the initial segment of adult male rat after treatment of estradiol benzoate or flutamide at 3 weeks of age

Expression of $C \times 31.1$ gene was not affected in the adult IS by treatment of EB at 3 weeks of age (Fig. 2A). There was no significant statistical change of $C x 31.1$ transcript levels in both EB-treated groups, compared with that in control group (Fig. 2A). Similarly, the treatment of Flu at 3 weeks of age didn't give an influence on the expression of $C \times 31.1$ in the adult IS, even though a slight increase of Cx31.1 transcript level, but not statistically significant, was observed with a high-dose Flu treatment (Fig. 2A). Com-
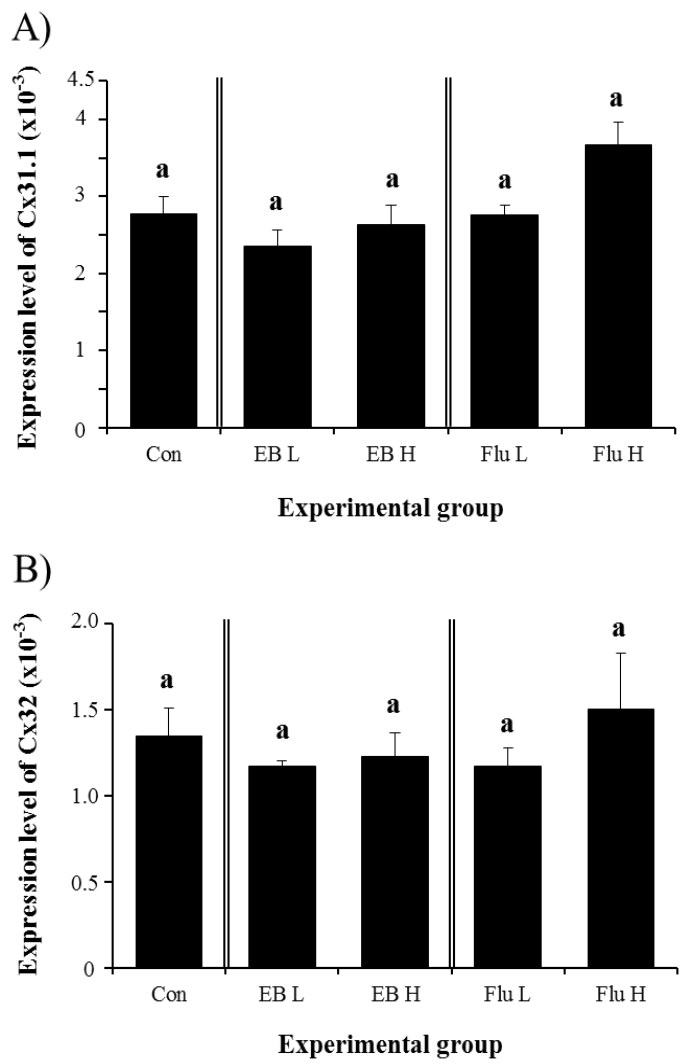

Fig. 2. Expression patterns of $C x 31.1$ and $C x 32$ genes in the initial segment of adult rat. Animals at 3 weeks of postnatal age were treated with either estradiol benzoate at low (EB L, $0.015 \mu \mathrm{g} / \mathrm{kg} \mathrm{BW}$ ) or high (EB H, $1.5 \mu \mathrm{g} / \mathrm{kg} \mathrm{BW}$ ) or flutamide at low (Flu L, $500 \mu \mathrm{g} / \mathrm{kg} \mathrm{BW}$ ) or high (Flu H, $50 \mathrm{mg} / \mathrm{kg}$ BW) dose. 
pared with the control, no significant change of $C x 32$ gene expression was detected in the adult IS treated with EB at 3 weeks of age (Fig. 2B). Also, the treatment of Flu at 3 weeks of age didn't cause expressional modulation of Cx32 gene in the adult IS (Fig. 2B).

\section{Expressional changes of $C \times 37$ and $C \times 40$ genes} in the initial segment of adult rat after treatment of estradiol benzoate or flutamide at 3 weeks of age

Expression of $C \times 37$ in the IS at the adult was significantly decreased by a low-dose EB treatment at 3 weeks of
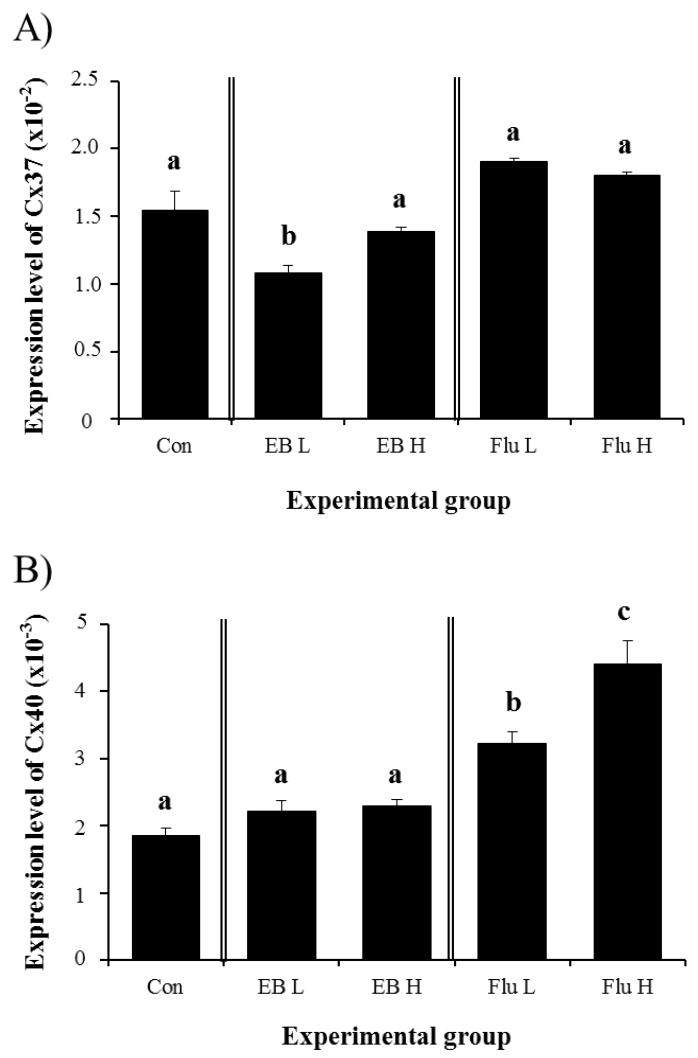

Fig. 3. Expression patterns of $C x 37$ and $C x 40$ genes in the initial segment of adult rat. Animals at 3 weeks of postnatal age were treated with either estradiol benzoate at low (EB L, $0.015 \mu \mathrm{g} / \mathrm{kg} \mathrm{BW}$ ) or high (EB H, $1.5 \mu \mathrm{g} / \mathrm{kg} \mathrm{BW}$ ) or flutamide at low (Flu L, $500 \mu \mathrm{g} / \mathrm{kg} \mathrm{BW}$ ) or high (Flu H, $50 \mathrm{mg} / \mathrm{kg} \mathrm{BW}$ ) dose. Different letters indicate statistically significant differences at $p<0.05$ level, compared with control. age (Fig. 3A). However, treatment of EB treatment at a high-dose didn't give an influence on expressional modulation of $C \times 37$ in the adult IS (Fig. 3A). None of Flu treatments at two different doses at 3 weeks of age caused significant change of $C x 37$ transcript level in the IS at the adult (Fig. 3A). Regarding expression of $C x 40$, treatment of EB at two different doses didn't result in significant expressional change in the adult IS (Fig. 3B). However, a treatment of Flu at a low-dose at 3 weeks of age led to a significant increase of $C x 40$ transcript level in the adult IS (Fig. 3B). A further statistically significant increase of $C \times 40$ gene expression in the adult IS was observed with a high-dose treatment of Flu at 3 weeks of age (Fig. 3B).

\section{Expressional patterns of $C x 43$ and $C x 45$ genes} in the initial segment of adult rat after treatment of estradiol benzoate or flutamide at 3 weeks of age

Expression of $C x 43$ in the IS of the adult was not changed by EB treatment at 3 weeks of age (Fig. 4A). Compared with the control, the transcript level of $C x 43$ gene in the adult IS treated with different doses of EB at 3 weeks of age was not significantly different (Fig. 4A). Treatment of a low-dose Flu at 3 weeks of age didn't cause any change on the level of $C x 43$ transcript in the adult IS (Fig. 4A). However, a significant increase of $C x 43$ expression in the IS of the adult was detected with a treatment of Flu at a high-dose at 3 weeks of age (Fig. 4A). Even though mean levels of $C x 45$ transcript in all experimental groups were lower than that in control group, transcript levels of $C x 45$ in EB- and Flu-treated experimental groups were not significantly different with that of control group (Fig. 4B).

\section{DISCUSSION}

Exogenous exposure to steroidal compounds during the early developmental period commonly accompanies disruption of hormonal homeostasis and gene expression in target tissues. Main concern of the present research was to examine 

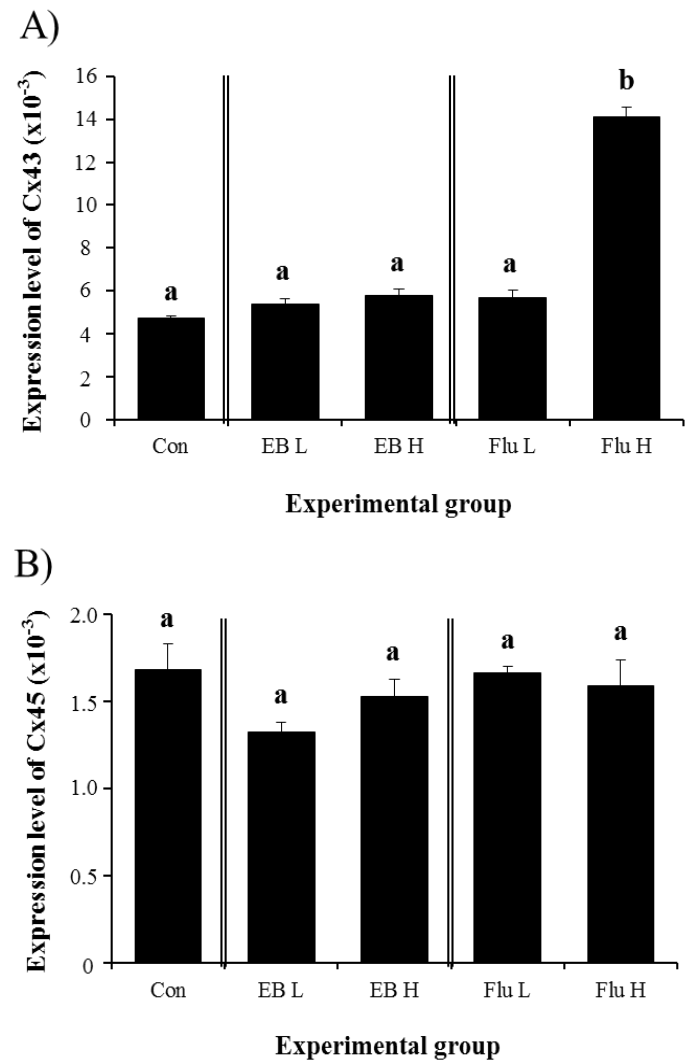

Fig. 4. Expression patterns of $C x 43$ and $C x 45$ genes in the initial segment of adult rat. Animals at 3 weeks of postnatal age were treated with either estradiol benzoate at low (EB L, $0.015 \mu \mathrm{g} / \mathrm{kg} \mathrm{BW}$ ) or high (EB H, $1.5 \mu \mathrm{g} / \mathrm{kg} \mathrm{BW}$ ) or flutamide at low (Flu L, $500 \mu \mathrm{g} / \mathrm{kg} \mathrm{BW}$ ) or high (Flu H, $50 \mathrm{mg} / \mathrm{kg}$ BW) dose. Different letters indicate statistically significant differences at $p<0.05$ level, compared with control.

the effect of steroidal agonist or antagonist treatment at the late neonatal age on the gene expression of $C x$ isoforms in the adult IS. Experimental results showed that consequences of administration of EB or Flu at 3 weeks of age were aberrant expression of some $C x$ isoforms, but not all, in the adult IS.

The most notable results from the present study are that expression of $C x 31.1,32$, and 45 genes in the adult IS was not affected by EB or Flu treatment at 3 weeks of age. Transcript levels of $C \times 31.1$ in the adult IS were signifi- cantly changed by treatment of low-dose EB or Flu to male rat at 1 week of age (Lee, 2014). The treatment of EB or Flu at 1 week of age caused expressional modi-fications of Cx32 and 45 after EB or Flu in the adult IS (Lee, 2014). A difference between the previous and current researches was only the age of experimental animal used. Even though the epididymal epithelium shares common cell types, such as principal and basal cells, the epithelium of IS possesses specific cell types, including apical and narrow cells (Robaire \& Hermo, 1988). Appearance of these cell types in the epithelium of epididymis is developmentally regulated. That is, until the first week after the birth, there is no obvious differentiation of the columnar epithelial cells in the IS (Robaire et al., 2000). The epithelial differentiation of the epididymis begins at the end of the first week after the birth, and completed at the puberty (Robaire et al., 2000). These reports indicate that the epithelium of IS at different postnatal age, especially during neonatal period, is likely organized with different cell types, and cellular composition of these cell types would vary during the early postnatal development. Moreover, expression of androgen receptor in the epithelium of epididymis during the early postnatal period is increased over time (You \& Sar, 1998), and the epithelium of IS possesses functional estrogen receptor (Cooke et al., 1991). Together, it would be reasonable to consider that responsiveness and sensitivity of the IS to estrogen and androgen vary with age during postnatal development, especially during neonatal period. These events could lead to differential expression of diverse molecules associated with differentiation and maturation of epithelial cells, thereby functional development of the IS. Based on this speculation, different expression patterns of $C x 31.1,32$, and 45 between the present research and a previous study (Lee, 2014) would result from different response to treatments of an estrogenic compound, EB, or an antiandrogenic compound, Flu, at different postnatal age, at least. Additional experiments 
conducted at other neonatal ages could provide more solid evidence on this assumption.

In the present study, significant increases of $C \times 30.3$ transcript level are only detected with Flu treatment, while treatments of EB or Flu of a high dose at 1 week of age result in significant increases of $C \times 30.3$ expression in the adult IS (Lee, 2014). Moreover, the previous research has shown significant a decrease of $C x 31$ expression in the adult IS by treatment of EB of a high dose or Flu of a low dose at 1 week of age (Lee, 2014). However, expression of Cx31 is significantly increased with EB treatment at 3 weeks of age. Such disagreements of results on gene expression would be due to differential responsiveness to steroid molecules exposed exogenously in the IS at different postnatal ages.

Treatments of EB or Flu at different neonatal ages also result in differential expression patterns of $C \times 37,40$, and 43 in the adult IS. Significant changes of $C \times 37$ transcript levels are detected with Flu treatment at 1 week of age (Lee, 2014), while a treatment of low-dose EB at 3 weeks of age only results in a decrease of $C x 37$ expression. A significant increase of $C x 40$ expression in the adult IS is detected with high-dose Flu treatment at 1 week of age (Lee, 2014), even though treatments of low- and high-dose Flu at 3 weeks of age lead to increases of $C x 40$ transcript level in the adult, as observed in the present research. Moreover, expression of $C x 43$ gene is significantly increased with EB or Flu treatment at 1 week of age (Lee, 2014), but only high-dose Flu treatment at 3 weeks of age induces a great increase of $C x 43$ transcript level. It is difficult to conclude how estrogen and/or testosterone influence on expression of Cxs in the IS at this point due to limited information available on regulation of individual $C x$ gene expression. Cry et al. (1996) have suggested expressional regulation of $C x 43$ in the adult epididymis by androgen. However, because this research was carried out in the adult experimental animals, the effect of androgen on $C x 43$ gene expression could not be directly applied to the findings from the present study. Future researches are required to determine a role of steroid hormones on gene expression of $C x$ genes in the IS during the early postnatal period.

In conclusion, it is clear that expression of $C x$ isoforms in the IS during the neonatal period is differentially regulated by estrogenic and androgenic molecules. However, it seems that transcriptional regulation of each $C x$ gene is controlled by these steroid hormones in dose- and/or agespecific manners. The present study shows a possibility of altered expression of $C x$ genes in the adult IS by exogenous exposure to steroidal substances at the early postnatal development.

\section{ACKNOWLEDGEMENTS}

This research was supported by Basic Science Research Program through the National Research Foundation of Korea (NRF) funded by the Ministry of Education, Science and Technology (20100022388).

\section{REFERENCES}

Adamali HI, Hermo L (1996) Apical and narrow cells are distinct cell types differing in their structure, distribution, and functions in the adult rat epididymis. J Androl 17:208-222.

Akingbemi BT, Hardy MP (2001) Oestrogenic and antiandrogenic chemicals in the environment: Effects on male reproductive health. Ann Med 33:391-403.

Carreau S, de Vienne C, Galeraud-Denis I (2008) Aromatase and estrogens in man reproduction: A review and latest advances. Adv Med Sci 53:139-144.

Cooke PS, Young P, Hess RA, Cunha GR (1991) Estrogen receptor expression in developing epididymis, efferent ductules, and other male reproductive organs. Endocrinology 128:2874-2879. 
Cosentino MJ, Cokett AT (1986) Structure and function of the epididymis. Urol Res 14:229-240.

Cyr DG, Hermo L, Laird DW (1996) Immunocytochemical localization and regulation of connexin 43 in the adult rat epididymis. Endocrinology 137:1474-1484.

Dubé E, Dufresne J, Chan PT, Cyr DG (2012) Epidermal growth factor regulates connexin 43 in the human epididymis: role of gap junctions in azoospermia. Hum Reprod 27:2285-2296.

Dufresne J, Finnson KW, Gregory M, Cyr DG (2003) Expression of multiple connexins in the rat epididymis indicates a complex regulation of gap junctional communication. Am J Physiol Cell Physiol 284:33-43.

Goodenough DA, Goliger JA, Paul DL (1996) Connexins, connexons, and intercellular communication. Annu Rev Biochem 65:475-502.

Han SY, Lee K-H (2013) The expression patterns of connexin isoforms in the rat caput epididymis during postnatal development. J Ani Sci Tech 55:245-255.

Jones RC (1987) Changes in protein composition of the luminal fluids along the epididymis of the tammar, Macropus eugenii. J Reprod Fertil 80:193-199.

Joseph A, Shur BD, Hess RA (2011) Estrogen, efferent ductules, and the epididymis. Biol Reprod 84:207-217.

Lee K-H (2013) Differential expression of multiple connexins in rat corpus ad cauda epididymis at various postnatal stages. J Ani Sci Tech 55:521-530.

Lee K-H (2014) Expressional modulation of connexin isoforms in the initial segment of male rat treated with estradiol benzoate or flutamide. Dev Rep 18:293-300.

Meşe G, Richard G, White TW (2007) Gap junctions: basic structure and function. J Invest Dermatol 127:25162524.
Pointis G, Fiorini C, Defamie N, Segretain D (2005) Gap junctional communication in the male reproductive system. Biochim Biophy Acta 1719:102-116.

Robaire B, Hamzeh M (2011) Androgen action in the epididymis. J Androl 32:592-599.

Robaire B, Hermo L (1988) Efferent ducts, epididymis, and vas deferens: structure, functions, and their regulation. In: Knobil E et al. (eds.). The Physiology of Reproduction. Raven Press, New York, pp 999-1080.

Robaire B, Syntin P, Jervis K (2000) The coming of age of the epididymis. In: Jégou B et al. (eds.). Testis, Epididymis and Technologies in the Year 2000. Springer, New York, pp. 229-262.

Sar M, Welsch F (2000) Oestrogen receptor alpha and beta in rat prostate and epididymis. Andrologia 32:295-301.

Seo H-H, Seon C-W, Choi I, Cheon Y-P, Cheon T-H, Lee K-H (2010) Expressional profiling of connexin isoforms in the initial segment of the male reproductive tract during postnatal development. Reprod Dev Biol 34: 103-109.

St-Pierre N, Dufresne J, Rooney AA, Cyr DG (2003) Neonatal hypothyroidism alters the localization of gap junctional protein connexin 43 in the testis and messenger RNA levels in the epididymis of the rat. Biol Reprod 68:1232-1240.

Temple-Smith PD, Zheng SS, Kadioglu T, Southwick GJ (1998) Development and use of surgical procedures to bypass selected regions of the mammalian epididymis: effects on sperm maturation. J Reprod Fertil Suppl 53:183-195.

You L, Sar M (1998) Androgen receptor expression in the testes and epididymides of prenatal and postnatal SpragueDawley rats. Endocrine 9:253-261. 